\title{
De aspecto quase florido. Fotografias em revistas médicas paulistas, 1898-1920*
}

James Roberto Silva

Doutorando - USP

RESUMO

Neste artigo, procura-se refletir sobre a natureza e o significado das fotografias impressas nas páginas das primeiras revistas médicas paulistas. Sua história está intimamente ligada ao crescimento e à urbanização experimentados por São Paulo a partir das últimas décadas do século XIX, à imigração, às seguidas epidemias que assombraram a capital e o interior do Estado, e às instituições científicas de saúde montadas na cidade.

Palavras-chave: fotografia; saúde pública; revistas médicas.
ABSTRACT

This paper is intended to nature and meaning of pictures appearing in the first medical journals of São Paulo. Their history is closely related to the city's rapid growth and urbanization in the late nineteenth century as well as immigration, continued epidemics which frightened the capital and the countryside and the establishment of scientific institutes in the city.

Keywords: photography; public health; medical journals.

O surgimento das principais instituições científicas de São Paulo ${ }^{1}$, até o fim da Primeira República, concentrou-se entre as décadas de 1880 e 1910, período também de enriquecimento, crescimento e urbanização intensos da capital. Nesse período de quase quarenta anos, São Paulo montou seu aparelho científico para atender aos imperativos comerciais, às pressões dos problemas urbanos e de saúde pública e também para manifestar sua ascensão econômica e política - conquistada paulatinamente no mesmo processo que a levou à condição de capital do Estado maior produtor mundial de café. $^{2}$

Nas décadas de 1880 e 1890, o Estado expandiu sua presença para a 
região oeste da cidade, instalando em 1880, no então longínquo Araçá (hoje, Av. Dr. Arnaldo) o Hospital de Isolamento e, em 1899, na fazenda Butantã, o Instituto Soroterápico do Butantã. Não tão afastado do Centro, foi localizado, ao norte, no bairro periférico do Bom Retiro, em 1893, o Desinfectório Central ${ }^{3}$. Nas atividades do Serviço Sanitário e de suas várias seções, a fotografia foi instrumento bastante presente, constituindo um importante documento sobre o uso dito científico (representado especialmente pelas publicações médicas) que faziam do recurso fotográfico e sobre o discurso médico e institucional que se fabricava por meio das fotos.

\section{A SAÚDE PÚBlica EM SÃo PAUlO}

Em São Paulo, na passagem do século XIX para o XX, adoecer era uma perspectiva assustadora e muito presente para enorme parcela da população urbana ou rural. Na capital, a concentração humana, aliada às precárias condições de habitação, de higiene e dos serviços públicos expunha principalmente os moradores da periferia da cidade a graves riscos de doenças. Centenas, às vezes, milhares de pessoas eram vitimadas, todos os anos, pela febre amarela, tuberculose, varíola, etc., num compasso que nem o desenvolvimento das técnicas profiláticas e curativas nem a montagem de serviços de saúde acompanhavam. A manutenção do fluxo da imigração estrangeira, sobretudo a italiana, acalentada pelo governo paulista e por fazendeiros, fosse para preencher ocupações urbanas na capital, fosse para labutar nas lavouras de café, exigia garantias de níveis mínimos de saúde, satisfeitas em parte pela criação do Serviço Sanitário do Estado de São Paulo, com suas várias seções.

Tributária das riquezas geradas pelo café, a capital, mesmo com as novas arquiteturas e os novos moradores, com a intensificação das atividades terciárias e, logo, com o surgimento de indústrias, não produziu respostas inclusivas aos problemas que surgiram com esses elementos e com a urbanização muito rápida e pouco planejada. Como medida profilática, dentre outras estratégias procurava-se, nem sempre com sucesso, separar os universos das classes por meio da diferenciação visual e espacial urbana e da repressão. Isto não impediu que um clima caótico se instalasse, disseminando o temor nos que ainda se acreditavam saudáveis; o horror às doenças e epidemias incontroláveis, sem tratamento eficaz ou conhecido - mas também o horror às multidões de desesperados, que 
compunha o imaginário social nas cidades industrializadas ${ }^{5}$, prenhe de aglomerações de renhidos -, crescia à medida em que ameaçavam ultrapassar as fronteiras da pobreza e atingir os cidadãos abastados. Lançando mão de projetos urbanísticos segregadores, como a normatização do uso da cidade ${ }^{6}$, a elite, representada pelo Estado, procurava gerenciar através da intervenção técnica problemas e tensões cujas raízes tinham origem nos atritos sociais e de classe.

Situa-se no final do século XVIII, segundo Foucault, o início do processo que vai gerar, por volta da segunda metade do século XIX, na França, a "medicina social", concebida para atuar sobre pobres e trabalhadores da cidade. Precedida pela "medicina urbana" - que objetivava organizar e controlar certos elementos presentes no espaço urbano, tais como o ar, a água, os serviços e os mortos, com vistas ao bem estar dos habitantes -, a "medicina social" vai se voltar contra pobres e operários num momento em que conviver com eles no espaço urbano passa a representar um perigo à sociedade burguesa, seja porque se revoltavam ou podiam facilmente aderir a agitações, seja porque se tornaram menos indispensáveis ao funcionamento de serviços urbanos essenciais, seja porque eram alvo fácil de epidemias, assim tornando-se transmissores em potencial'.

Semelhante situação vivia São Paulo, constituindo o cenário para a intervenção do Estado, a quem restava conjugar, convenientemente aos interesses das classes dominantes da época, os fatores cura, doença, controle, população e produção. A febre amarela, o cólera, a varíola, a peste bubôni$\mathrm{ca}$ - crônicas, sucessivas e, às vezes, simultâneas - eram de fato temíveis e, conforme a visão médica do período, alojavam-se principalmente na pobreza. No entanto, os pobres, que se confundiam com trabalhadores de todo tipo, constituíam mão-de-obra necessária. A convergência de projetos modernizadores convocava à participação o sanitarismo e o higienismo, como meios de criar um ambiente de progresso (higiene, ordem, etc.) com fins de propaganda para os países provedores de imigrantes. Numa espécie de alinhamento científico ${ }^{8}$ o país tinha também de demonstrar capacidade logística e científica para conter as pulsões urbanas e as doenças que circulavam em suas fímbrias, abalando o fluxo das mercadorias, do capital e da mão-de-obra (fatores estes que podiam denegrir ainda mais a imagem de atraso do país já construída no estrangeiro).

Efetivamente, o caráter da intervenção sanitária ultrapassou o âmbito público, o espaço urbano comum. Se em nome da saúde coletiva, as atividades e a permanência humanas na cidade, sobretudo de trabalhado- 
res e desocupados (hábitos, trabalho, circulação, comércio informal, higiene, aglomerações), passaram a ser normatizadas, também a vida privada dos desfavorecidos tornara-se assunto público, sendo freqüentemente invadida sob os argumentos da medicina ou da força. Maria Clementina Pereira Cunha ressalta que os cortiços eram locais especialmente visados pela polícia sanitária, porquanto muito temidos como focos de moléstias e de degradação humana. "Espécie de síntese do mal, objeto de todos os temores", os cortiços sofriam todo tipo de intervenção, direta e indireta; eram alvo de desinfecções constantes ou mesmo de desocupação e demolição; seus moradores tinham suas roupas seqüestradas para incineração ou desinfecção se havia a ocorrência de alguma doença contagiosa; e viviam sob o risco de serem afastados da cidade e ter de morar distante, às margens dos trilhos, nas terras sem valor ou, no caso de alguns trabalhadores de indústria, alojarem-se em vilas operárias criadas por seus patrões.

\section{A FOTOGRAFIA IMPRESSA NAS REVISTAS MÉDICAS PAULISTAS}

Para registrar as atividades dos serviços de saúde pública de São Paulo, patrocinadas pelo Serviço Sanitário - especialmente desde o final da década de 1890, quando se encontravam em franco processo de institucionalização ${ }^{10}-$, fotografias foram produzidas copiosamente cobrindo muitos dos aspectos que caracterizavam as ações dos médicos e das instituições de saúde, com empregos e temáticas variadas: fotomicrografias, radiografias, retratos de pacientes e doentes, fotografias de órgãos humanos, de cadáveres, de animais, de instalações sanitárias, composição de álbuns fotográficos para divulgar a instituição, registro de atividades de pesquisa, retratos de personalidades da área médica, registro das etapas de construção dos próprios institutos, eternização das fachadas dos prédios que lhes serviam de sede, documentação de diligências sanitárias pela capital e pelo interior, etc. Depois, esses registros podiam tomar diversos destinos como figurar em álbuns institucionais, tornar-se material de estudo ou ir para os arquivos, servir de propaganda política ou para fins de divulgação ${ }^{11}$.

Parcela significativa das fotografias, produzidas seja institucionalmente, seja por iniciativa particular de médicos, tinha por finalidade ilustrar os artigos científicos publicados em revistas médicas ${ }^{12}$ como as que existiam em São Paulo naquela época: Revista Médica de São Paulo (desde 
1898), Gazeta Clínica (1903), Imprensa Médica (1904), Annaes Paulistas de Medicina e Cirurgia (1913) e Monografias do Serviço Sanitário (1918-20) ${ }^{13}$. Sendo bastante variado o leque de temas registrados fotograficamente, o que se observa no caso das revistas médicas são imagens de células contaminadas, de fetos malformados, esqueletos humanos, moribundos atacados pela sífilis, doentes com verminoses, crianças portadoras de poliomielite, pacientes incapazes de locomoção (Fig. 1), grupos familiares inteiramente enfermos, latrinas impropriamente instaladas, moradias insalubres, esgotos a céu aberto.

O mundo da enfermidade estava cercado pela fotografia, desde as menores di-

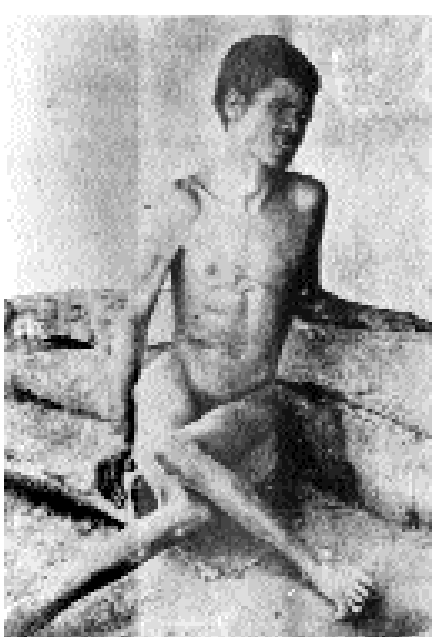

(Fig. 1) Forma nervosa da diphlegia cerebral - Idiota completa”. RMSP , n. 17, 1912. mensões até o ambiente "promíscuo" no qual viviam os grupos considerados sob riscos: indigentes, trabalhadores, pobres e moradores de cortiços. Nem todas as enfermidades, porém, costu-

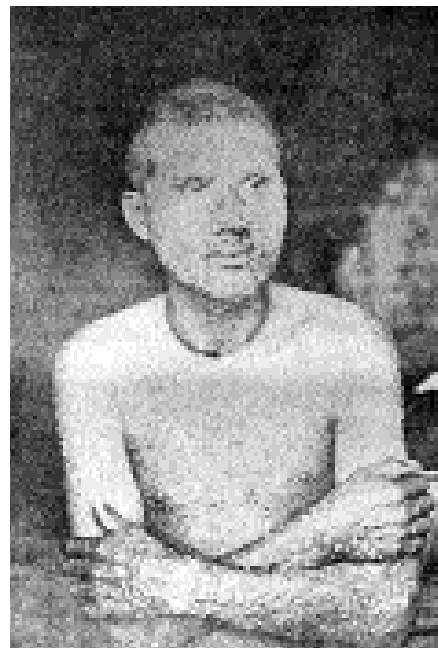

(Fig. 2) Paciente afetado por alastrim, uma febre eruptiva. RMSP, n. 17, 1910. mavam habilitar seu portador a ser fotografado; elas precisavam ter alguma visibilidade como sinais na pele, no corpo, ou afetar a aparência ou a coordenação motora do paciente. Não há, por exemplo, fotografias de pessoa(s) com gripe ou mesmo com febre amarela, mas as deformidades, presentes nos portadores de leishmaniose, bócio e alastrim, isto é, as anomalias, protuberâncias e erupções, estas apareciam com freqüência nas páginas das revistas especializadas (Fig. 2), cuja provável maioria de leitores era de médicos. Essas mesmas imagens estavam ausentes dos álbuns oficiais, em que tudo era mostrado sob o império da organização e da assepsia. ${ }^{14}$

É notável a escassa incidência de pa- 


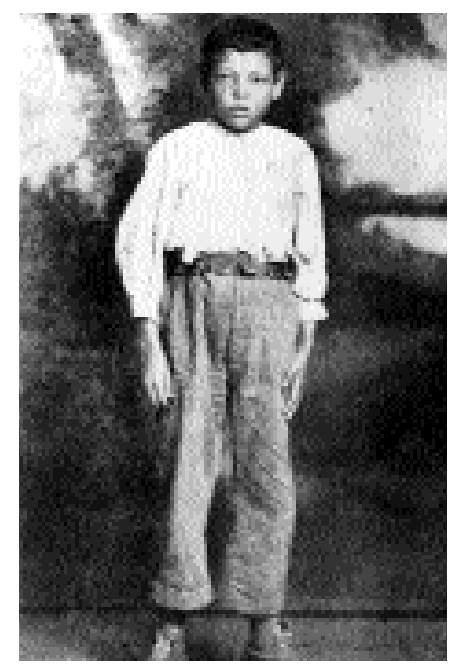

(Fig. 4) "Antonio de tal”, doente de verminose MSS, v. II, n. 13, 1920.

cientes acometidos de enfermidades como ancilostomose, verminose, hipoglicemia, ou seja, sem sintomas visualmente aparentes ou evidentes. Suas raras aparições ocorrem em registros feitos em algumas campanhas do Serviço Sanitário por cidades do interior. Nessas imagens esboça-se um tipo social, uma aparência física e um temperamento daquela população interiorana: pacientes com expressão entre atônita e desconfiada, indefesos, com braços pendidos, abatidos e em trajes rústicos. O mesmo esforço em advertir para os sintomas subjetivos das moléstias atuava também na estigmatização da população humilde e pobre do interior como ignorante e infantil (Fig 4). Estigmatizado agora também nas fotogra-

fias, esse homem interiorano já possuía "marcas” registradas na pintura paulista (o exemplo mais recorrente é a tela Caipira picando fumo, 1893, de Almeida Jr.), notadas por Monteiro Lobato que, numa premonição irônica, imaginava arqueólogos, num futuro distante, recuperando a imagem do caipira como a de um picador de fumo. ${ }^{15}$

Nas composições, nas poses e no repertório exposto nas fotografias das revistas médicas salta uma caracterização do brasileiro, não qualquer, mas daquele passivo de adoecer, exposto aos riscos da insalubridade, das submoradias, da ignorância. O tipo social e a ambientação que figuram nas fotos, por sinal, sempre remetem à pobreza, o que faz crer que o problema da saúde, na concepção de médicos e cientistas, era algo inerente à situação material. Sob uma visão preconceituosa da etiologia das doenças, a condição do doente ganhava, atravessadamente, seus contornos sociais.

As estampas mostram também que a tipificação de um segmento social era estabelecida, dentre diversas maneiras, pelo confronto com o outro. Em algumas fotos em que pacientes aparecem na companhia de médicos (Fig. 5), fica pronunciada a diferença social entre eles, designada pelas roupas, mas não só: pela posição que ocupam no ambiente e na composição fotográfica, pelas atitudes assumidas: enquanto, em geral, o 
paciente tem de encarar a câmara, ficando mais exposto, "paralisado", médicos ou enfermeiros assumem poses que sugerem movimento e ocupação, a execução de $\operatorname{algo} \mathrm{o}^{16}$. O mundo dos gabinetes médicos e dos laboratórios também era assunto presente nas estampas fotográficas. Seqüências fotográficas documentando campanhas de saúde, principalmente as do interior, surgidas, por exemplo, nas Monografias do Serviço Sanitário, traziam entre suas primeiras fotos as dos ambientes do laboratório, do posto médico, do escritório e dos funcionários ressaltando limpeza, ordem, organização e aparatos técnicos e de locomoção (Figs. 6 e 7).

A pesquisa em torno desse gênero de

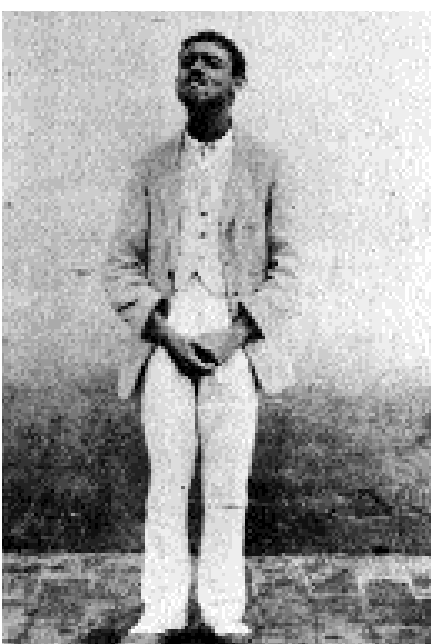

(Fig. 5) "Tino, um bom amigo", doente de ancilostomose MSS, v. I, n. 1, 1918. fotografia - levando-se em consideração a maneira como se encontra distribuído em arquivos e bibliotecas - implica refletir sobre algumas questões, tais como quantificar a produção fotográfica das instituições de saúde, o que esbarra no problema da classificação, da conservação e da guarda desse material. As imagens fotográficas da saúde em São Paulo que restaram apresentam-se sob quatro condições: avulsas (1) (em geral, com indicações sumaríssimas ou mesmo sem

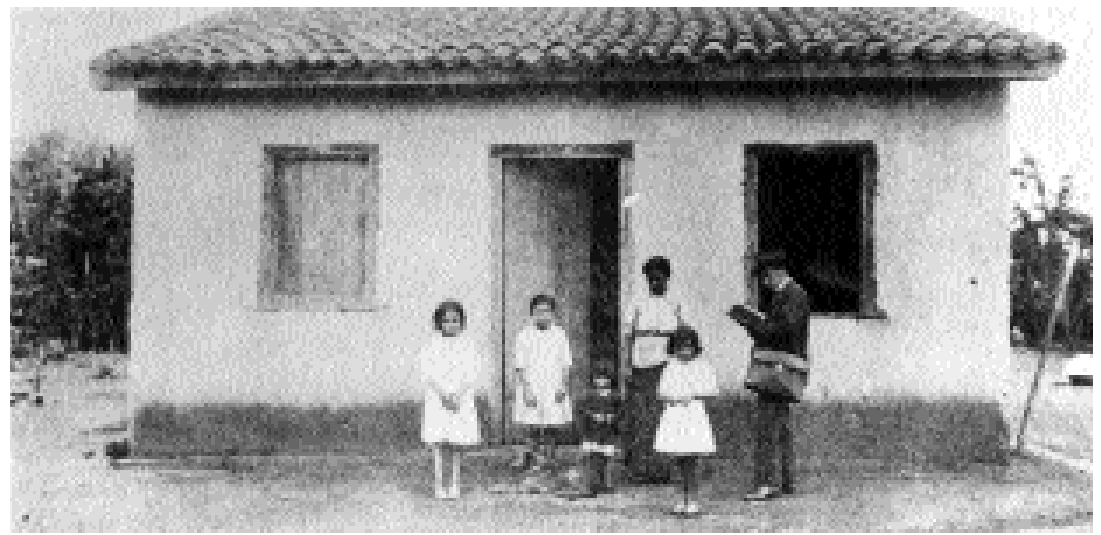

(Fig. 6) Médicos em visita aos doentes da zona rural, em campanha contra a ancilostomose. MSS, v. I, n. 1, 1918. 


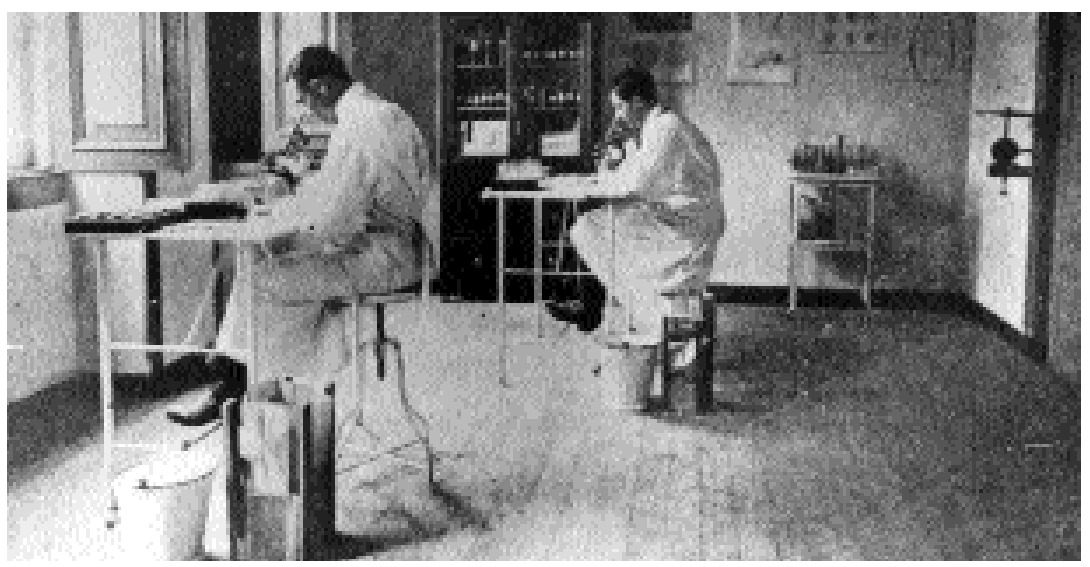

(Fig. 7) "Laboratório - Microscopistas, em trabalho." MSS, v. I, n. 1, 1918.

nenhuma, tais como as existentes nos acervos do Museu de Saúde Pública Emílio Ribas (São Paulo) e do Centro de Memória Iconográfica da Faculdade de Saúde Pública da Universidade de São Paulo; impressas em revistas científicas (2); em álbuns (3) da lavra das próprias instituições; em relatórios (4) dirigidos à Secretaria do Interior ou ao governo do Estado. Saber em que proporção está o material que restou em relação ao total produzido é tarefa talvez impossível, pois não há indícios de quanto se produziu (como ofícios solicitando, exigindo ou sugerindo a produção de fotos, requerimentos, recibos a fotógrafos ou estúdios fotográficos, relatórios de balanço, textos orientando sobre um possível uso científico da fotografia, etc.), nem garantias quanto à integridade dos acervos - ao contrário, boa parte certamente foi perdida. Conhecer precisamente as características dessa perda é também improvável. Pode-se, no entanto, observando-se atentamente o que foi salvo, supor que tenha havido aí a intervenção de algum critério, que talvez devesse remontar à armazenagem mais ou menos cuidadosa providenciada para umas e outras fotos no período mesmo em que foram produzidas - ou logo posteriormente, quando então as administrações sucessoras tinham de resolver o destino daquele material. Nestes casos, é então possível supor - mas difícil afirmar - que fotos julgadas de menor importância relativa tivessem sido guardadas em locais pouco adequados, ficando sujeitas à deterioração precoce ou mesmo ao descarte.

Diante disso, um trabalho efetuado sobre tal conjunto de fotogra- 
fias apenas pode estabelecer relações de proporção quanto àquelas que aparecem nas revistas, pois é o tipo de apresentação mais regular e sob a qual mais imagens ainda existem de forma contextualizada e minimamente referenciada por estarem contidas em artigos datados, que dão informações como local, produtores, assunto, às vezes os autores, etc.

Mesmo eliminando ao máximo os fatores de incerteza, esse tipo de operação, quantitativa, possui contudo suas implicações de ordem metodológica das quais gostaria de me desviar neste artigo. Felizmente, tais implicações não impedem iniciativas de interpretação qualitativa sobre esse material. Se a análise por meio de números permite reconhecer as tendências tanto quanto as exceções ou as ausências, encaminhando as conclusões para o campo das generalizações, o estudo mais pormenorizado de grupos documentais restritos possibilita captar nuanças e particularidades das fotografias, sutilezas reveladoras, sinais a ressignificar imagens aparentemente normativas. É buscando esta abordagem que passarei a manejar um certo conjunto de fotografias publicadas em 1914 num periódico médico paulista.

\section{"DE ASPECTO QUASE FLORIDO"}

“De aspecto quase florido” (...), "Nas faces de Dej. Lop. aqueles lábios túmidos consentem..."

As frases acima não constam de um folhetim publicado na imprensa mundana, nem o dr. Julio Novaes, que as talhou, foi, ao que se saiba, romancista nas horas vagas. Elas pertencem a um relato médico, publicado numa edição de 1914 da Gazeta Clínica e o seu autor, dr. Novaes ${ }^{17}$, é quem trata do caso da senhorita Dej. Lop.. Se não bastasse a linguagem adornada, chamam também a atenção as fotografias da paciente que ilustram o artigo. $\mathrm{O}$ dr. Novaes confeccionou um texto incomum ao assunto para se referir aos sintomas sofridos por uma paciente aparentemente também incomum. Pelas descrições feitas, fica sugerido que o dr. Novaes partilha de alguma intimidade com a família da moça e, se não a comparte também com ela, ao menos se permite certas fantasias a seu respeito. Sobre o pai, sabe o doutor de sua profissão e seu bobby ("burocrata e músico"), sabe descrever em detalhes seus cacoetes e o julga um degenerado por seus "atos sociais"; da mãe, conhece as doenças, o estado das partes íntimas e o resultado de cada um de seus treze partos. De Dej. Lop., sabe - ou imagina - seu modo de compor o penteado, seus afazeres de moça caseira, que seu sono é restaurador e que tem "gênio" difícil. 
O cuidado com o texto, a atenção do médico, seu conhecimento de tantos detalhes são dignos de um paciente diferenciado, pois não são regra e sim exceção. Em toda literatura especializada que me foi possível pesquisar, nenhum outro paciente merecera tão rebuscada descrição traço bem perceptível ao se comparar os rasgos de escritor do doutor Novaes quando se refere a Dej. Lop. com a descrição que mereceu um outro senhor, este paciente do dr. J. Alves de Lima: "João Siq., de 34 anos de idade, é mulato, brasileiro, casado, operário agrícola, de estatura regular e constituição robusta" ${ }^{18}$. Isto é tudo.

Os textos científicos desse período não raro traziam longos preâmbulos, cheios de floreios e evocações a grandes nomes, porém, quando adentravam efetivamente no assunto a linguagem, embora sem perder a grandiloqüência, torna-se essencialmente técnica. Nos relatos de tratamento de doentes o mais comum era ver as descrições salpicadas de reprovações aos hábitos do paciente, de referências negativas à cor da pele e à sua condição de mestiço, etc. (esses pacientes, com os quais o médico não tinha identificação social, eram sempre pessoas pobres e humildes; pessoas de posses não sofriam tal exposição e normalmente eram tratadas em casa ou em clínicas e casas de repouso particulares). O caso de 210 Dej. Lop., desse modo, constitui exceção por sua condição social e pelo interesse e gentileza a ela dispensados pelo médico, conotando, a um tempo, discriminação e valorização social. Ao aproximar o seu universo e o do paciente, o médico manifestou aceitação e identificação.

Luc Boltanski observou o comportamento de médicos franceses em

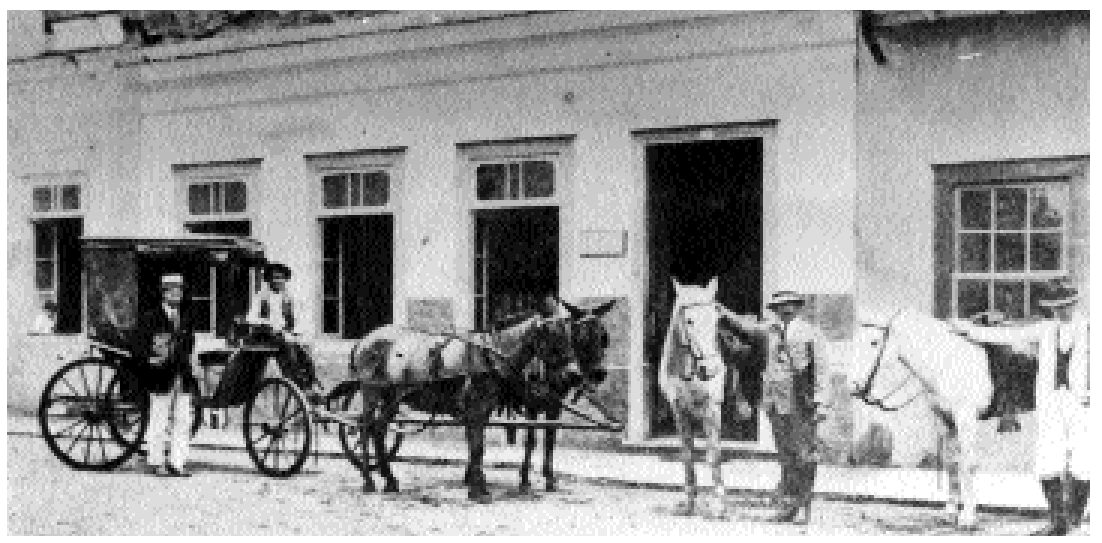

(Fig. 8) "Partida para o trabalho - enfermeiros da zona rural" MSS, v. I, n. 1, 1918. 
consulta com pacientes de diferentes estratos sociais em 1967 e 1968 . Notou, por parte dos médicos, o uso da linguagem, de atitudes mais ou menos afetuosas e de sua posição profissional como recursos de distanciamento ou aproximação do paciente conforme a posição deste na hierarquia social. As razões apontadas foram da ordem do preconceito, da não identificação e da subestimação da capacidade de pacientes humildes compreenderem as explicações mais elementares ${ }^{19}$.

Como assinalado anteriormente, as fotografias publicadas nas páginas das revistas médicas, a despeito de serem explicadas por legendas e de avizinhar-se das descrições etiológicas e patogênicas, cons-

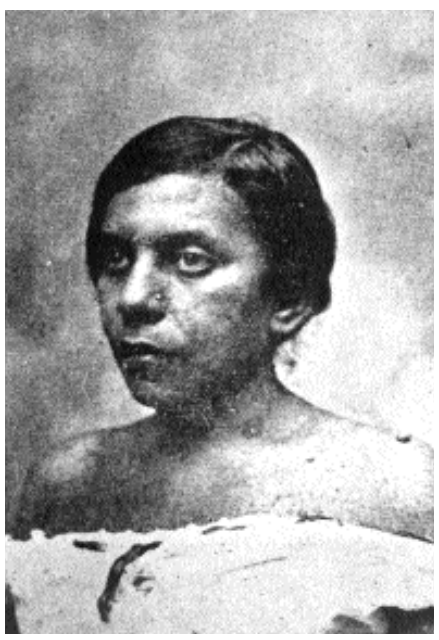

(Fig. 9) "Signal de hertoghe com beiços carnudos." GC, n. 21/22, 1914. tituíam um discurso paralelo ao texto e construíam um perfil social e psicológico da população humilde, maciçamente visada, devassando-lhe o

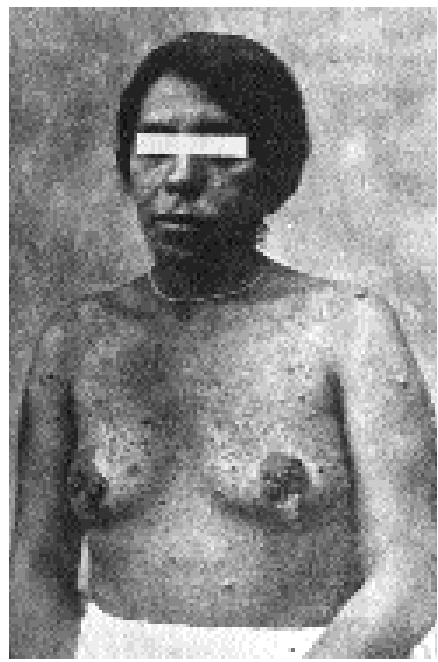

(Fig. 10) "Dermo-neurofibromas contellados nas areolas dos seios sob o typo cheloide." GC, n. 21/22, 1914.. corpo e a privacidade. A publicação do caso da paciente do dr. Novaes constitui um caso particular e como tal é apresentado, em palavras e imagens. Sete fotografias do corpo de Dej. Lop. ilustram o artigo: três são frontais, duas de costas e duas de detalhes, pé e braço. Protegida apenas por um panejamento (espécie de fraldão, que em nada correspondia ao vestuário íntimo feminino da época), sem nada a lhe cobrir os seios, a paciente foi fotografada em pé e de corpo inteiro.

As curiosidades começam quando, depois de aparecer com o rosto descoberto na primeira página do artigo (Fig. 8), nas seguintes (Figs. 9, 10, 11) ela leva uma tarja branca nos olhos a lhe esconder a identidade. Posto que se julgava tratar da mesma pessoa representada em todas as 
fotos, as tarjas nos olhos não mais cumpriam o papel de velar a identidade da moça. Mas os pruridos moralistas faziam-nas constar como índices da honestidade e pudicícia da jovem, mesmo quando oferecia à câmara seios, ventre e coxas desnudos.

Mas Dej. Lop. não está totalmente despida: além do pano cobrindo o baixo ventre e o púbis, ela continua vestindo meias e sapatos, não somente sinais da formalidade preservada, mas também índices de como se veste e de qual estrato social provém, denunciados pelos calçados e pela gargantilha. A moça de família, cujo nome é apenas insinuado, não está destituída de tudo ao posar, ela ainda preserva seus adornos de classe (Figs. $9,10,11)$.

A reforçar essa condição, estão alguns elementos presentes como "fundo" nas fotos 10 e 11 e numa fotografia de detalhe (Fig. 12). O fundo contém uma discreta folhagem pintada (Figs. 10 e 11), típico elemento cenográfico com que os estúdios de fotografia dotavam a composição para fabricar sentidos como bucolismo, elevação ou ligados à natureza, à aventura e à viagem. No caso das fotos da paciente, as folhagens pinta-

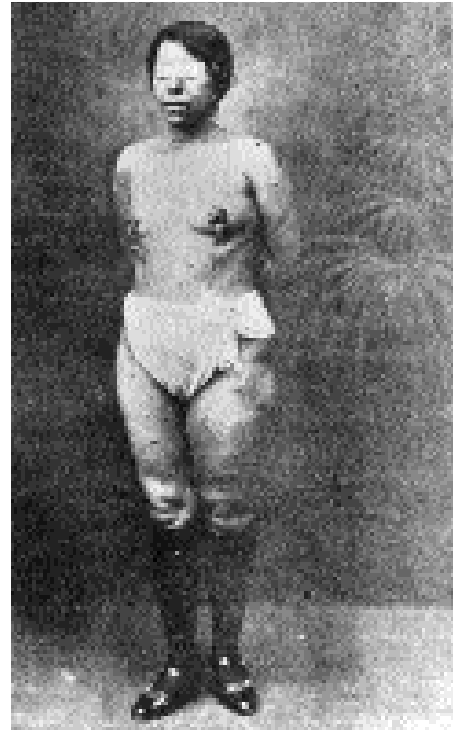

(Fig. 11) "A doente se modela bem as formas femininas com regular panicula adiposa.” GC, n. 21/22, 1914 ..

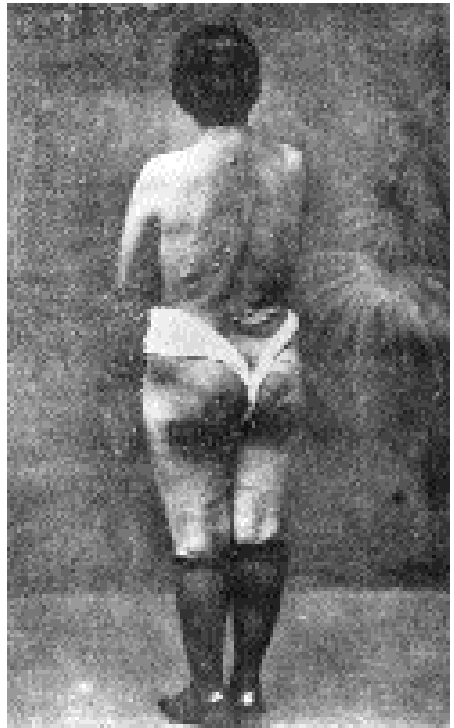

(Fig. 12) "A neurofibroma gluteal (...) dando a sensação de ar deslocável ao palpar com os dedos em pinça." $G C, \mathrm{n}$. 21/22, 1914.. 


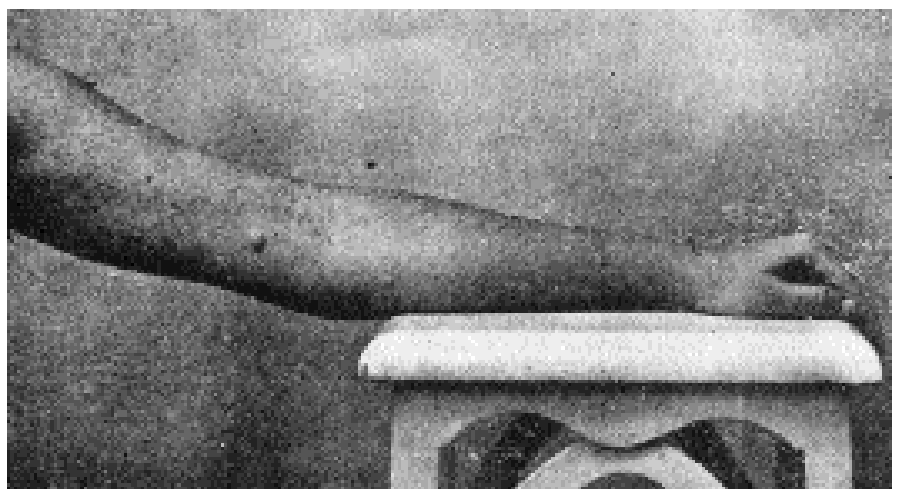

(Fig. 13) "”Dermo-neurofibroma do braço com pigmentação discreta." GC, n. 21/22, 1914.

das na tela de fundo funcionam emprestando seus atributos de natureza, de casualidade e delicadeza à pose da fotografada e à situação, o que ameniza a estranheza do conjunto. A leve assimetria da posição dos pés e a atitude dos braços revelam, por sua vez, que a modelo (ou paciente, como um dia já se chamou os que posavam para fotografias) ${ }^{20}$ foi dirigida pelo fotógrafo, a fim tanto de suavizar a composição quanto de caracterizar a entrega de Dej. Lop. aos seus cuidados e aos do médico.

O outro elemento que entra em cena como item de refinamento está presente na foto 13: trata-se do apoio para o braço. O uso de apoio(s) para registro de partes do corpo não era comum nas fotografias médicas, nem tampouco os elementos eventualmente presentes em fotos de doentes possuíam beleza e elegância. No entanto, é justamente o oposto que se constata na imagem. O que vemos sob o braço da moça talvez fosse uma banqueta, um pequeno aparador ou um apoio para vaso, pouco importa, o efeito pretendido estava alcançado: a harmoniosa combinação de mármore e madeira, retas e curvas transmitia suas qualidades ao braço resultando numa composição delicada para um assunto indigesto.

\section{CONCLUSÃO}

Para concluir este artigo, gostaria ainda de adicionar uma observação sobre uma das legendas sob as fotos de Dej. Lop. Trata-se de um comentário que tece um elogio às formas da moça e que pertinência alguma tem com os sintomas. A legenda inteira diz: "A doente se modela bem às formas femininas com regular panícula adiposa. Há na coxa poucos fibro- 
mas e manchas congênitas. O esqueleto é normal.' A fotografia (Fig. 10) e a legenda em questão surgem na página 223 da revista. Uma página adiante, o dr. Novaes retomará o mote: "O corpo de Dej. Lop. é todo envolto por uma camada de panícula adiposa bem modelando as formas femininas" (grifos meus), remetendo novamente o leitor para as fotos 10 e 11 . Constaria no subtexto dessa mistura de termos técnicos ("panícula adiposa") com ideal plástico feminino ("bem modelando as formas femininas") a prática de um voyeurismo médico ou de um "especialista"?

No caso do dr. Novaes, talvez. Mas no caso do médico e psicoterapeuta Gaiarsa, nosso contemporâneo, certamente sim, pelo que ele próprio afirma em seu opúsculo sobre o corpo ${ }^{21}$. Lá, ele atribui ao desejo de ver e tocar outros corpos sua escolha pela medicina, já que nessa profissão atos assim tornam-se permitidos e legitimados. A confissão de Gaiarsa e o "olhar" do dr. Novaes introduzem na atividade científica um quociente de subjetividade difícil de desconsiderar. Intenções ou interesses e até perversões e neuroses - de todo tipo, a princípio e aparentemente estranhos à atividade científica, povoam as cabeças de cientistas (o que dirá a dos fotógrafos?) e pessoas ligadas a esse meio, tema já explorado em diversos filmes exibindo cientistas (às vezes, malucos) com teorias e 214 projetos obscuros e em nada objetivos, humanitários ou desinteressados como no clássico Dr. Fantástico, de Stanley Kubrick, ou nos mais recentes Os doze macacos, de Terry Gillian e Contato, de Robert Zemeckis.

A pergunta, mais que uma simples resposta afirmativa ou negativa, instiga a refletir sobre os possíveis ou verdadeiros móveis que levam ao exercício científico ou o acompanham mas que não são formalmente considerados como parte da doutrina nem da prática de qualquer ciência. Nem por isso cai a validade da atividade científica mas a defesa da objetividade, da neutralidade e da universalidade como atributos indeléveis da ciência fica mais difícil de sustentar.

Mesmo aquelas fotografias tomadas durante atividades científicas institucionais prestavam-se a "dizer" - ou denunciar - algo do que pensavam seus produtores a respeito do que faziam ou daquilo que documentavam. Em seu impulso sobre os objetos de estudo, médicos e higienistas estavam longe daquela isenção que se supõe ser a marca do espírito científico. Daí que fotografias aparentemente destinadas a alargar o conhecimento acerca de doenças muito mais concorriam para compor uma imagem do tipo social passível de contraí-las, cumprindo um papel na formação de um imaginário sobre o que era um doente e das características que o identificavam, dentre elas a da indolência, vista como resistên- 
cia aos tratamentos propostos pelos médicos, vale dizer, à racionalidade científica.

As fotografias publicadas em revistas, quase sempre acompanhadas por legendas, embora fossem editadas de acordo com o conteúdo dos artigos, tinham um discurso autônomo ou paralelo em relação aos textos; entremeadas à descrição de uma campanha sanitária, as fotos desempenhavam o papel de valorizar a instituição e seu corpo médico enquanto projetavam as noções de hierarquia e de submissão que desejavam ver assimiladas pela população.

\section{NOTAS}

* A realização deste trabalho contou com o apoio do Museu de Saúde Pública Emílio Ribas (SP).

${ }^{1}$ Hospital de Isolamento (1880), Comissão Geológica e Geográfica de São Paulo (1886), Instituto Agronômico de Campinas (1887), Instituto Bacteriológico (1892), Instituto Vacinogênico (1892), Desinfectório Central (1893), Escola Politécnica (1893), Museu Paulista (1895), Instituto Escola de Farmácia (1898), Instituto Butantã (1899), Escola Superior de Agricultura Luiz de Queiroz, de Piracicaba (1901), Faculdade de Medicina (1913), Instituto Pasteur (1916) e Instituto de Higiene (1918).

${ }^{2}$ Para uma visão que compreende a introdução das ciências no Brasil e sua institucionalização como um processo também social e político, ver DANTES, Maria A. M.. Fases da implantação da ciência no Brasil. Quipu, México, mai./ago.1988, pp. 265-275.

${ }^{3}$ Sobre os critérios científicos que determinavam a localização das instituições e seu processo de instalação, ver para o caso do Instituto Butantã: BENCHIMOL, Jaime L. e TEIXEIRA, Luís A.. Cobras, lagartos e outros bichos. Uma história comparada dos institutos Oswaldo Cruz e Butantan. Rio de Janeiro: Editora UFRJ, 1993. pp. 13-4; e para o caso do Desinfectório Central: OLIVEIRA, Jandira L.. O Serviço Sanitário de São Paulo: primeiros tempos, primeiras instituições. Guia da Exposição Permanente. São Paulo: Museu da Saúde Pública Emílio Ribas, CPTM, CADAIS, Secr. Est. Saúde; datilografado, 1994.

${ }^{4}$ Inicialmente, as seções eram: Desinfectório Central, Hospital de Isolamento, Instituto Bacteriológico, Instituto Butantã, Laboratório de Análises Químicas e Bromatológicas e Instituto Vacinogênico. Cf. RIBEIRO, Maria Alice Rosa. História sem fim... Inventário da saúde Pública. São Paulo - 1880-1930. São Paulo: Editora da UNESP, 1993.

${ }^{5}$ Cf. CUNHA, Maria Clementina Pereira. 0 espelho do mundo. Juquery, a bistória de um asilo. Rio de Janeiro: Paz e Terra, 1986, p. 23.

${ }^{6}$ Ver o teor normatizador tanto dos Códigos Sanitários como dos Códigos de Posturas do Município de São Paulo, cuja versão do ano de 1886 mereceu os comentários críticos de Sérgio Milliet em Roteiro do café e outros ensaios: contribuição para o estudo da bistória econômica e social do Brasil. São Paulo: Hucitec; Brasília: INL, 1982. Os códigos citados são, respectivamente, Código Sanitário do Estado de São Paulo, São Paulo: Typographia do Diario Official, 1894, e Código de Posturas do Município de São Paulo, São Paulo: Typographia do Diario Official, 1886. 
${ }^{7}$ Cf. FOUCAULT, Michel. Microfísica do poder. Rio de Janeiro: Graal, 1981, pp. 80-95.

${ }^{8}$ Cf. ALVES, José Jerônimo de Alencar. Ciência pasteuriana e o projeto dominante de higiene e modernização na Primeira República. DIAS, André L. M. (org.). Perspectivas em epistemologia e bistória das ciências. Feira de Santana: UEFS, 1997, pp. 181-193.

${ }^{9}$ Ver CUNHA, op. cit., p. 36.

${ }^{10}$ Dentre outros autores, um dos que destacam o processo de institucionalização dos serviços de saúde em São Paulo é Simon Schwartzman, em Formação da comunidade científica no Brasil. São Paulo: Ed. Nacional; Rio de Janeiro: Finep, 1979. Para o caso do Rio de Janeiro, menciono o trabalho de Eduardo V. Thielen, em que se estuda o papel da fotografia na institucionalização dos serviços de saúde pública no Rio de Janeiro nas três primeiras décadas deste século, tendo no centro do processo o Instituto Oswaldo Cruz. Cf. Imagens da saúde do Brasil. A fotografia na institucionalização da saúde pública. Dissertação de Mestrado, PUC - São Paulo, 1992.

${ }^{11}$ Ver SILVA, James R. Fotogenia do caos. Fotografia e instituições de saúde - São Paulo, 18801920. Dissertação de Mestrado, FFLCH-USP, 1998, p. 48.

${ }^{12}$ Os periódicos eram, nacionalmente, em sua grande maioria, mantidos por entidades privadas locais, do tipo da Sociedade de Medicina e Cirurgia de São Paulo, esta responsável pela Revista Médica de São Paulo, fundada em 1898. Outras vezes, eram mantidas pelos próprios diretores da publicação, como no caso da Gazeta Clínica, do dr. Rubião Meira, criada em 1903.

${ }^{13}$ As séries de Monografias do Serviço Sanitário são compostas por artigos originalmente avulsos, publicados pelo Serviço Sanitário entre 1918 e 1920, e mais tarde reunidos em três volumes pelo Desinfectório Central.

${ }^{14}$ SILVA, op. cit., pp. 49-50.

${ }^{15} \mathrm{Na}$ previsão de Lobato, os arqueólogos, baseados nas telas, assim concluiriam : "Naquela metade de século, no Brasil, o caipira picava fumo." LOBATO, M.. Estética oficial, in. ___. Idéias de Jeca Tatu. São Paulo, Brasiliense: 1946. Sobre as atitudes e idéias de Monteiro Lobato perante as artes plásticas, ver CHIARELLI, Tadeu. Um Jeca nos vernissages. Monteiro Lobato e o desejo de uma arte nacional no Brasil. São Paulo: Edusp, 1995.

${ }^{16}$ SILVA, op. cit., pp. 50-2.

${ }^{17}$ NOVAES, Julio, Um caso de moléstia recklinghausen. Gazeta Clínica, n. 21/22, ano XII, 1914, pp. 221-225.

${ }^{18}$ LIMA, J. Alves de. Elefantíase no escroto. Gazeta Clínica, n. 3, ano III, 1905, pp. 114-118.

${ }^{19}$ BOLTANSKI, Luc. As classes sociais e o corpo. $2^{2}$ edição. Rio de Janeiro: Graal, 1984, pp. 45-7.

${ }^{20} \mathrm{MACHADO}$, Arlindo. A ilusão especular: introdução à fotografia. São Paulo: Brasiliense/Funarte, 1984. p. 52.

${ }^{21}$ GAIARSA, José A.. O que é corpo. $7^{\text {a }}$ edição. São Paulo: Brasiliense, 1995, pp. 7-8.

Artigo recebido em 06/2000. Aprovado em 03/2001. 